\title{
LINEAGES OF ISLAMIC EXTREMISM IN EGYPT Ikhwan al-Muslimun, State Violence and the Origins of Radical Politics (1923-1981) ${ }^{1}$
}

\author{
Ali Munhanif*; M. Dahlan** \\ *Syarif Hidayatullah State Islamic University (UIN) Jakarta; \\ **Alauddin State Islamic University (UIN) Makassar \\ Email:ali.munhani@@uinjkt.ac.id
}

\section{Abstract}

This article examines why an Islamic organization appeal into radical behavior? Focusing on Ikhwan al-Muslimun (IM) and its splinter groups in Egypt, this article seeks to highlight historical-institutional underpinnings of when and how political Islam faced obstacles to enter pragmatic politics. Political experiences of the IM in the 1950s and the institutional structures created by Nasser's regime in the early 1960s have shaped a condition of uncertainty that constrained Islamist activists to twart moderation. Islamist thinkers such as Sayyid Qutb exploited the fear of Nasserism and new emerging state institutions, to convince many members that they were threatened by the current regime. Initiatives to embrace radical ideology and actions have become dominant frameworks in the IM. The extent to which this radical ideology may develop is not only because of these institutional constraints, but also because of the absence of pragmatic-minded leaders who appealed with non-violence ideas to

1 This article is part of our research project of "Negotiating Democracy: Civil Society and the Politics of Democratization in Egypt and Indonesia." The fieldwork portion of this project is funded by the Center for Research and Publication (PUSLITPEN), the State Islamic University (UIN), Syarif Hidayatullah, Jakarta, under International-Collaborative Research Support in 2017. We would like to express our thanks to Wahdi Sayuti who have made the institutional support possible. We are grateful to Dadi Darmadi, Jajang Jahroni, and Badrus Sholeh (UIN Jakarta) for their reading and comments to the earlier draft of this article. 
integrate Islamic agenda in institutional opportunities.

[Tulisan ini membahas organisasi Islam yang cenderung menjadi radikal, studi kasus Ikhwan al-Muslimun (IM) dan pecahannya di Mesir, dengan mengulas secara organisasional historis disaat Islam politik tersebut mendapat rintangan ketika memasuki politik praktis. Pengalaman politik IM tabun 1950an dan 1960 an saat dibawah rezim Nasser telah membawa ketidakpastian dan yang menyebabkan para aktifis menjaubi sikap moderat. Seorang Sayyid Qutb pun mengangkat ketakutan pada kekuasaan ręim Nasser untuk meyakinkan massa pada sebuah ancaman baru. Cara berpikir dan bertindak radikal telah menjadi piliban yang dominan bagi anggota IM. Kesuburan pabam radikal tersebut dimungkinkan karena tidak banya adanya tekanan organisasional, tetapi juga tiadanya tokoh politik yang mendorong pendekatan non kekerasan dalam integrasikan agenda politik dengan peluang organisasioanal.]

Keywords: Egypt's politics, Ikhwan al-Muslimun, Islamic state, institutions, religious ideas.

\section{A. Introduction}

The post Cold War world, especially after the terrorist attack on the World Trade Center in New York, on September 11, 2001, there is growing concern with Islamic radicalism and extremism perceived as the breeding ground for contemporary religious violence. This trend has produced a confusion in explaining its emergence, ideas, politics, and in categorizing its various components. In this article we explore the political origins of Islamist radicalism, many of them reflected and amplified in the behavior of Ikhwan al-Muslimun and its splinter groups in Egypt.

Our argument is that Islamic organizations such as Ikhwan alMuslimun originated from a religious-reform movement and a political ideology that includes a search for state-formation alternative during the late colonial period. An extreme interpretation of Islam has therefore become the spearhead of religion engaging in a counterattack on secular state and Western domination which had reduced its power at that time. By drawing on the gradual changes of state-Islamist relation in Egypt, this article seeks to provide an explanation on why militant Islamic ideas and radical political actions have emerged in the country's political landscape? We argue that the emergence of new state system and institutions created 
by Gamal Abdul Nasser since the late 1950s have created a condition of uncertainty that constrained Muslim activists in Egypt. Islamist thinkers and ideologues exploited the fear of Nasserism and the new emerging state, and therefore advocated many Islamist cadres to embrace radical actions drawing the lines to uphold revolutionary path against the Nasser's state.

Ikhwan al-Muslimun (IM) emerged as leading institution for the mobilization of Islamic state in Egypt. Its foundation marked three important concerns in Egyptian politics and society: the 1924 abolition of Islamic Caliphate, strong appeal of Western-liberal thoughts that resulted in attack on Islamic faith, and continued presence of British occupation in Egypt's independence. The understanding of this early episode of initial rise and failure of liberal experiments under Westernized elite provide a background for the analysis of organizational characters of the IM. It allows us to establish proposition that, the declining legitimacy of Egyptian state and its secular foundation of national identity breed the founders of the IM to revitalize Islam as an alternative for state formation.

We adopt historical-institutional approach in this study to argue that it is the role played by the institutions of Nasser's regime-including social, political and constitutional ones - that facilitated the changing character of mobilization for Islamic state. ${ }^{2}$ By establishing these institutional responsibilities and relationship to other actors', the processes of ideology creation, transformation, and the strategy for mobilization will be portrayed at the IM's choice to stand against the secular state. We admit that scholars on Islamic politics have developed approaches to the study of radicalism. However, most theoretical discussions have focused on Islamic ideology and particular set of political development. It is interesting to note that although many dimensions of politics are embedded in the mechanism of Islamic radicalization processes, they ignored the dynamic of institutions developed during Nasser's regime that shaped the changing behavior of the IM and their activists.

Institutions, therefore, are a central point in our analysis to

${ }^{2}$ Historical institutionalism has been used to analyze many contemporary political phenomena. The topic varies, from political economy, state formation, secession, to the study of political regime. For comprehensive elaboration on this approach, see Peter A. Hall and Rosemary C.R. Taylor, "Political Science and the Three New Institutionalisms", Political Studies, vol. 44, no. 5 (1996), pp. 936-57. 
interrogate the processes of ideology creation, transformation, and politicization which serve as analytical core in the politics of Islamic movements. We define institution here as a materialized structure of the nation-state. ${ }^{3}$ This definition refers to what Peter A. Hall ${ }^{4}$, a scholar who developed institutional analytical frameworks, recalled as an analysis which seeks to conceive institutions "as the formal, informal procedures, routines, norms, and conventions embedded in the organizational structure of the polity (institutions) can range from the rules of a constitutional order or the standard operating procedures of a bureaucracy to the conventions governing trade union behavior". By recognizing these institutional environments in crucial phase of state formation we will be positioned to understand the lineages of Islamic extremism and violence in Egypt.

This article therefore employs three perspectives to interrogate our case within the historical institutional framework. First is authoritarian politics perspective which argues that common national basis for modern state require a strong regime, usually military, to uphold national integration. By stressing on the cultural history of national groups, this article suggests that Islamist movements define themselves by reference to a particular teaching of religious glory. Should they embrace a national concept which is in the intersection of their religious identity controlled by members of non-religious leadership, they will defend their inalienable rights to retain control of their own culture, ideas and identities. ${ }^{5}$ Second is social economic deprivation. It argues that Muslim politics has its roots in the uneven nations' economic development between the modern nation-states and the traditional, religious societies. Such a relationship may be the result of "modernization policies" undertaken by the new states. Perceptions of relative deprivation may develop, and they generate demands for a "better bargain" from religious clerics and their institutions.

3 Kathleen Thelen and Sven Steinmo, "Historical Institutionalism in Comparative Politics", in Structuring Politics: Historical Institutionalism in Comparative Analysis, ed. by Sven Steinmo, Kathleen Thelen, and Frank Longstreth (Cambridge: Cambridge University Press, 1992).

${ }^{4}$ Hall and Taylor, "Political Science and the Three New Institutionalisms", p. 17.

5 John L. Esposito, Islam and Politics (Syracuse: Syracuse University Press, 1984); Y. Haddad, "Sayyid Qutb: Ideologue of Islamic Revival”, in Voices of Resurgent Islam, ed. by John L. Esposito (Oxford: Oxford University Press, 1983), pp. 67-98. 
If the demands are ignored, these religious societies will call for rebellion legitimated by reference to religious-secular differences. ${ }^{6}$ Third, the middle class thesis which argues that new emerging Muslim middle class seek to promote their interest in politics by acting as religious-political activists. These members of middle class are identified as the educated youth to uphold control in political arena. ${ }^{7}$ Rather than taking a side in single theoretical framework, we take eclectic position to combine those perspectives in explaining the origins of Islamic extremism.

\section{B. Politics, Ideology, and State-Formation in Egypt: A Historical Background}

Before the 20th century Egyptian society was traditional and religious in character, and yet the circumstances in which the modern state was formed have been such as to promote the identification of the state with political ideology embraced by dominant elite landed-class associated with liberal, secular vision of the state. Muslim majority of the populace have been sidelined from being the back bone of the state formation processes, both in the sense that the early initiative of anticolonial organizations for statehood came to be virtually monopolised by the liberal landed-elite and, more importantly, in the westernizing character of national constitution. In the Egypt's cultural context, liberal governments under monarchy were perceived as both British-backed national state and an agent for the secularization of Egyptian society.

The process of state formation in modern Egypt can be traced back to the long period of the country's struggle for independence since the first half of the 20th century. British domination of Egyptian national life had increased exponentially since their occupation of Egypt which began in 1882. By 1906, growing levels of popular discontent with British rule led to a period of national political and economic crisis that would not end until the military coup of 1952. Historians of Egypt noted that while the new emerging political parties were seeking to claim for themselves the mantle of 'defender of Egyptian sovereignty', they were simultaneously

${ }^{6}$ Mohammed M. Hafez, Why Muslims Rebel: Repression and Resistance in the Islamic World (Boulder: Lynne Rienner Pub, 2003).

${ }^{7}$ Carrie Rosefsky Wickham, Mobilizing Islam: Religion, Activism and Political Change in Egypt (New York: Columbia University Press, 2002). 
being wracked by internal divisions that prevented them from effectively handling the social and economic problems of the pre-independence period. ${ }^{8}$ Prolonged and seemingly intractable political and social turmoil in Egypt engendered searching national self-analysis, particularly among its political elite, its intellectuals and ulama, as regards the sources of the country's degradation at the hands of European powers.

From this period of crisis, new social, religious, and political movements emerged in the early 20th century organized along two ideological lines: Islamic reformism ${ }^{9}$ and liberalism. ${ }^{10}$ Both camps felt that modernization of the Egyptian state was a social good, but they differed as to how it could best be achieved. Leaders of both ideological camps also felt that the Western constitutional system of governance could be a model of reform that would benefit Egypt, but they differed as regards how they should adopt the system and reconcile it with Islamic tradition. Important social groups behind the call for the liberal constitution were Egypt's landed elite, British civil administrators, judges, and other new middle-class actors who had graduated from Western-style Egyptian

8 Bruce K. Rutherford, Egypt after Mubarak: Liberalism, Islam, and Democracy in the Arab World (Princeton: Princeton University Pres, 2008), pp. 14-6. Historians of Egypt consider this period as moments of identity crisis in nation building. It was the result of numerous factors linked to the process of modernization initiated a century earlier by Muhammad Ali, the Ottoman governor of semi-independent Egypt. He came to power in 1803, and later continued by his successor, Khedive Ismail (1863-1879). These two founders of modern Egypt had initiated far reaching economic, political and military reforms to industrialize Egypt along Western lines.

9 The Islamic reformists were led by Muslim thinkers such as Muhammad Abduh (1848-1905) and later, Rashid Ridha (1868-1935). These reformers advocated revitalizing Islam and adapting it to modern conditions. The Muslim reformists held, Egyptian could find models of effective governance and spirit of scientific progress that would form the basis for selective borrowing from the West. See Albert Hourani, Arabic Thought in the Liberal Age, 1798-1939 (Cambridge: Cambridge University Press, 1983).

10 The prominent figures of liberalism were composed of Western-oriented intellectuals who were educated in the West or, at least, graduated from Western-style of learning institutions in Egypt. They include Thaha Husein, Mohammad Haykal, and Mufti as Sayyid. At the forefront of liberal political movement was the Wafd Party (Delegation Party). When the party was established in 1919, it was called originally with the Hizb al Amni, which means the Secular Party. 
schools. $^{11}$

These forces helped to ensure that the Constitution of 1923 followed the spirit of European Enlightenment ideals, and reflected three clear principles of modern statecraft: the state being constrained by laws that define the purpose and scope of state power and through checks and balances on its constituent parts; the society being governed by the principle of "the rule of law"; and the state guaranteeing the rights of its citizens, including the protection of freedom of speech, assembly, and religion. ${ }^{12}$ Importantly, the British-Ottoman agreement that followed the collapse of the Ottoman Empire after World War I officially kept Egypt a British colony. Thus the Ottoman Khedive (Muhammad Ali dynasty) "was now recognized as a king, and, under British military protection, headed a state based on a model from European constitutional monarchies". ${ }^{13}$ Egypt continued to be governed in this fashion until the Free Officers' coup in 1952.

From its inception, the liberal constitution faced serious challenges. The problem of "rule of law" was an issue in Egypt following the British attempt to force the King to adopt a European code of law. ${ }^{14}$ Moreover the adoption of the new constitution outraged many Egyptians, who perceived the King as a British pawn due to his decision to adopt a code not based on Islamic law. The ulama responded to this constitution by forcefully re-entering the political scene, defending their authority by insisting that the national law of Egypt should be based on a codified body of Islamic jurisprudence, fiqh. ${ }^{15}$ But the marginalization of ulama that has taken place since Mohammed Ali's modernization policies, coupled with the expansion of Western education and ideas, meant that their message was relatively easy to ignore. Indeed, the adoption of a

11 Clark Benner Lombardi, "State Law as Islamic Law in Modern Egypt: The Amendment of Egyptian Constitution and the Article 2 of Jurisprudence of the Supreme Constitutional Court of Egypt", Ph.D Dissertation (Columbia: Columbia University, 2001), p. 74.

12 Ibid., pp. 81-98.

13 Ibid., p. 119.

14 Rutherford, Egypt after Mubarak: Liberalism, Islam, and Democracy in the Arab World, pp. 40-2.

15 Daniel Neil Crecelius, “The Ulama and the State in Modern Egypt”, Ph.D Dissertation (Princeton: Princeton University, 1967), pp. 146-54. 
liberal constitution became in effect the blow to the ulama's previously prominent place in public affairs. As Petersen pointed out, by the 1920s, the "traditional ulama and their guilds became a weak institution, largely without influence in the political affairs". ${ }^{16}$

It was under these circumstances, the post-Ottoman Egypt being torn between its liberal constitution and one based on Islamic law that, the idea of the Islamization of the modern state through constitutional means began to circulate. This idea produced an impetus for further elaboration of certain aspects of Islamic constitutional thought. ${ }^{17}$ Around a dozen organizations were established mostly adopted the "renaissance of Islam" in their names and advocated "Islam as an alternative of state formation". ${ }^{18}$ These organizations might have differed in terms of social base and forms, but shared common rejection of Egypt's liberal constitution. They also sought a total transformation of Egyptian state espousing for Islamic shari'a as the corner stone of the political aspiration of these organizations.

In this period too, new elites emerged echoing patterns found in many other parts of the colonial Middle East. When formal independence of Egypt was gained in 1923 but signalled a continued presence of the British rule a growing anti-secular, anti-liberal state began to materialize. A number of political organizations thus sprang as alternatives of state formation: the radical right wing of nationalists, Misr al Fata (Young Egypt), modeled on the fascism in Gemany and Italy, organized in 1930; The Association of Muslim Youth (Jama'at al-Shubban al Muslimun, YMMA) was founded in 1927. Between 1927 and 1935 around a hundred organizations were established. They adopted the renaissance of Islam in

16 Ibid., p. 101. The ulama, especially those affiliated with the Azhar, were largely sidelined politically. The struggle for the institutionalization of Islamic law in modern Egypt came to be led by "modern emerging activists". In the 1930s, the struggle for an Islamic state was gradually transformed into a popular cause under the inspiration of this new type of Muslim generation. See, Christina Phelps Harris, Nationalism and Revolution in Egypt: The Role of the Muslim Brotherhood (Berkeley: Stanford University Press, 1964), pp. 41-2.

17 Rutherford, Egypt after Mubarak: Liberalism, Islam, and Democracy in the Arab World, p. 73.

18 Harris, Nationalism and Revolution in Egypt, p. 141. 
their names. ${ }^{19}$ Other left organizations that composed of the communists and socialists were formed in the early 1930s. These include a secret organization within middle-rank military personnel that later came to be known Free Officers movement. All these organizations differed in terms of social base and ultimate goals, but shared common rejection of liberal constitutional state and "a need for capable and energetic leadership for Egypt". ${ }^{20}$

It was under this calamitous political situation and economic hardship of much of the working population in Egypt that a fairly small religious association was founded: the Society of the Muslim Brothers. Founded in Isma'iliyya in 1928 by a school teacher, Hasan al-Banna (1906-1949), the Ikhwan al-Muslimun was designed initially as a social organization conceived in religious term as "a living community...for religious and moral reform to (spreading) the message of Islam". ${ }^{21}$ Like other intellectuals of his time, Hasan al-Banna was concerned about the state of the Egyptian nation and society. In many of his opinion, contemporary Egypt was epitomized by political turmoil and disunity, increasing moral laxity, decreasing respect for tradition and religion. In a response to the increasing influence of liberalism, Hasan al-Banna even noted, "Egypt has witnessed the widespread enthusiasm for Western secular culture among the upper and middle classes". 22

As a larger part of anti-British occupation and a reaction to the decline of liberal state, the IM envisioned Islam as an alternative solution for the state crisis. Hasan al-Banna repeatedly advocated a rapid transition to a full independence and "called for the establishment of a government derived from Islamic constitutions". ${ }^{23}$ Distinctive programs in various economic and social initiatives of the IM captured the grievances of the Egyptians and, above all, tapped Islam to have had an unexpectedly

19 J. Heyworth-Dunne, Religious and Political Trends in Modern Egypt (Washington: Publ. by the author, 1950), pp. 106-11.

20 Harris, Nationalism and Revolution in Egypt, p. 142.

21 Hasan al-Banna, Five Tracts of Hasan al-Banna (1906-1949), trans. by Charles Wendell (Berkeley: University of California Press, 1978), p. 11.

22 Richard P. Mitchell, The Society of the Muslim Brothers (New York: Oxford University Press, 1993), p. 215.

23 Banna, Five Tracts of Hasan al-Banna (1906-1949), p. 17. 
powerful appeal. Hasan al-Banna did not set out to craft the IM as a mass-based political movement. Instead, he devoted much attention to education and to village welfare work in a method reminiscent of Sufi sects understood by al-Banna as an educational movement for the "reform of hearts and minds". ${ }^{24}$

Hasan al-Banna called for "the purification of Muslim societies through the return to the Qur'an and the Sunnab of the Prophet as the main source for the establishment of an Islamic system". ${ }^{25}$ The organization was thus originally conceptualized as a modest religious association, with a limited but innovative social program. From its start, the IM established its own social welfare network, providing essential healthcare and other social services to the poor, particularly valuable during the worldwide economic downturn of the 1930s. ${ }^{26}$ The IM also set about establishing an independent economic base for itself and to this end, created enterprises in fields as diverse as weaving, transportation, and construction, and even quite progressively offered employees stock options in its companies. ${ }^{27}$

Facilitated by a conviction that benevolent social activism formed an integral part of Islam's social ethos, such programs accounted for the dramatic rise of the IM's role as a key player in Egyptian politics. While political and other social organizations lost their vigor and cohesiveness largely because of economic downturn, the IM established itself as the fastest growing organization in post-independent Egypt. Between 1928 and 1930, when the IM begun formally operating its programs in Isma’iliyya neighborhood, Hasan al-Banna had been successful in building a disciplined-community to represent "a model of Islamic system". The system constitutes voluntary organizations integrated within Islamicreligious characters among their members. It is built upon the principles of totality of Islam which includes schools, social clubs, boy scouts,

${ }^{24}$ Sami Zubaida, "The Quest for the Islamic State", in Islam, the People and the State: Political Ideas and Movements in the Middle (New York: Routledge, 1989), p. 47.

25 Mitchell, The Society of the Muslim Brothers, p. 191.

26 Ishaq Musa Husayni, The Moslem Brethren: the Greatest of Modern Islamic Movements (Westport: Hyperion Press, 1956), pp. 71-3.

27 Wickham, Mobilizing Islam, p. 154. 
newspapers, health clinics and mosques. ${ }^{28}$

The IM called for the dismantling of borrowed secular institutions of government. But the IM's struggle did not simply amount to the advocacy of a return to an obsolete, outmoded way of life. Rather, theirs was a more sophisticated prescription for remedying Egypt's ills. It has been said that the IM was (and remains) "an effort to reinstitutionalize religious life for those whose commitment to the tradition and religion is still great, but who at the same time are already effectively touched by the forces of Westernization". ${ }^{29}$ Hasan al-Banna posited the reestablishment of a "pure" Islam as the foundation for all social intercourse and a definitive cure for society's afflictions. Only through the creation of a society based on the total application of Islam could Egypt (and, by extension, the Arab and Islamic worlds) emerge victorious from its unavoidable encounters with modernity. ${ }^{30}$ According to Hasan al-Banna, Egypt had to be purified of the taint of the British as well as the secularized political elite who steered Egypt into its political and economic decline.

Later in the late 1930s, when the conflicts between the IM and other political groups grew, Hasan al-Banna made explicit proposals intended as a clear formulation of what he imagined as an Islamic state. He declared:

We want an "Islamic government" that will lead these people to the mosque and guide people through the mosque thereafter through guidance of Islam. For these reasons, we do not recognize any governmental system which is not founded on the basis of Islam or derived from it. We do not recognize these political parties, or these traditional forms which the infidels and the enemies of Islam have forced us to rule by and practice. We will seek to revive the Islamic system of rule with all its

${ }^{28}$ In 1940 it developed into 500 branches with around one million active members. In 1954, the IM has registered itself as the largest organization with 2000 branches and 2 million active cadres.

29 Mohammad Amien Rais, "The Muslim Brotherhood in Egypt: Its Rise, Demise, and Resurgence", Ph.D Dissertation (Chicago: The University of Chicago, 1981), p. 153.

30 See, William L. Cleveland, A History of the Modern Middle East (Boulder, Colo: Westview Press, 1994), pp. 184-7. Hasan al-Banna cautioned his followers that as "the shari'a was originally formulated to meet a specific set of historical circumstances. It was thus a product of informed human reasoning which, through careful interpretation, would permit its adaptation to modernity". 
manifestation and form. ${ }^{31}$

Hasan al-Banna's strong concern with the role of state in public moral purity led the IM's program to focus on how Quranic inspiration enters the daily life of Muslims. Hasan al-Banna perceived a widespread flagging of emotional commitment to Islam but expected a solution from the existing political elite. He specifically addressed this problem in the sermon "Naẓrāt fì iṣlāh al-Nafs" (Remarks on Self-reform), with its striking central image of electricity. In his view, "if the effect of Qur'an is not the same in us as it was in our ancestors then we are like an electrician who has put insulation between himself and the current so that he is not affected by it. Our task is to break down this insulation so that we can feel the Qur'an so that our hearts will be in communication with it and we will taste its sweetness". ${ }^{32}$ For Hasan al-Banna, today Muslims were emotionally insulated from the Qur'an, but he did not connect this insulation with an institutional foundation.

In February 1949, Hasan al-Banna was assassinated. The assassination marked an important development of the IM. At this early stage, the IM had no formal organization intended to be directly involved in politics, and their activities revolved around an education approach. The strong inclination to struggle for moral purity in increasingly secular and industrializing Egypt, has led the IM leadership to enter politics without being transformed into a political organization. Their basic message was that purist, religious characters of political interest of the IM's leadership was shaped by the conditions of 20th century Egypt in which of pro-long, unsolvable political crisis and socioeconomic downturn occurred. Such moments of decision are crucial sites of interaction between ideology and political context.

\section{Nasser's Revolution and State Violence}

The prolonged and unresolved crisis in Egypt has shaped a situation in which the anti-British organizations, including the IM, begun to develop revolutionary ideas for political changes. Three

31 Hasan al-Banna, Majmu at rasa'il al-Imam al-shabid Hasan al-Banna (Beirut: Dar al-Da'wa, 1990), p. 32.

32 Hasan Al-Banna, "Naẓrāt fī iṣlāh al-Nafs", in Tazłkirat al Hasan Al-Banna (Cairo, 1956). 
organizations were operating at this revolutionary situation: the Ikhwan al-Muslimun, the Free Officers Movement, and -in less organized formthe Communists. ${ }^{33}$ The first two organizations were widely seen as the most capable of bringing about real political change. Both harbored ill feelings toward the Egyptian regime and Britain, but differed in terms of their goals. The IM was a civilian organization that, until the early 1950s, remained the only mass-based opposition whose aim of establishing an Islamic state was well known. The Free Officers was an organization put together by 200 dissident military officers following the 1948 Arab-Israeli war. ${ }^{34}$ Led by Gamal Abdel Nasser and Mohamad Najib and other middle rank officers, the Free Officers launched a bloodless coup on July 23rd, 1952 against King Farouk. In hours the two centuries of the monarchy had collapsed.

One of the most significant challenges to the Free Officers after the coup came from the well-organized Ikhwan al-Muslimun. Crucial aspect of the struggle between the two organizations involved differences on what form Egyptian society would take: Nasser's plan was to restructure Egypt along socialist and 'secular' lines, while the IM emphasized a state based on the implementation of shari'a in guiding the people. ${ }^{35}$ Recent account on the role of the IM has revealed that the coup was in fact the result of a well planned, or at least coordinated, operation between the IM leadership and Nasser's Free Officers. ${ }^{36}$ These studies have also emphasized that it was the military factions of the IM that firmly opted for working with Nasser to help launch the coup. ${ }^{37}$

33 Harris, Nationalism and Revolution in Egypt.

34 Joel Gordon, Nasser's Blessed Movement: Egypt's Free Officers and the July Revolution (New York: Oxford University Press, 1992), p. 19.

35 It must be noted, Nasser's ideology was initially not clear. His socialist and secular-leaning political system was adopted later when the conflict between Free Officers and the Ikhwan escalated.

36 Omar Ashour, "Lions Tamed? An Inquiry into the Causes of DeRadicalization of Armed Islamist Movements: The Case of the Egyptian Islamic Group", Middle East Journal, vol. 61, no. 4 (2007), pp. 596-625.

37 Ibid., pp. 88-90. King Farouk's legitimacy following the 1948 Arab-Israeli war was very low, particularly between November 1951 and March 1952. This period was marked by riots and demonstrations in Cairo, Alexandria and Isma'iliyya. Riots against the King broke out in Cairo, eventually leaving a "greater part of the city's business 
The absence of dominant organization in the coup also means that, the Free Officers' coup of July 1952 was distinguished by its lack of ideological content. ${ }^{38}$ The character of the new military regime was thus shaped by the leadership's pragmatic policy choices, ${ }^{39}$ particularly the desire to stay in power. The Free Officers were committed to several broad goals: achieving national independence from Britain, improving the country's military preparedness, reforming the political system to stamp out corruption, and achieving a higher level of social justice. ${ }^{40}$ These goals were largely compatible with the short-term plans of the IM, which included ending the British occupation, establishing a stable and clean political system, and narrowing the gap between the rich and the poor. ${ }^{41}$ But the political processes aimed at constitutional reform led to a series of events that fed a relentless pattern of power competition between the Free Officers and other revolutionaries, particularly the Ikhwan.

Open conflict between the Free Officers and the IM drew ever nearer. Nasser began to prepare to launch strikes against opposition forces. Although the Free Officers expressed their commitment to maintaining the 1923 Constitution, Nasser was in intense critics of the Wafd, which he accused as having betrayed the national cause by approving of the Anglo-Egyptian Agreement on the Suez Canal in 1936. ${ }^{42}$ This conviction caused the Free Officers to attack against the party system in 1953. All parties were banned, their papers were closed, and their leaders were arrested and put on trial. Another decisive step taken by the Free Officers — one that was at odds with the liberal constitution-was land reform. This step was "the most decisive act" of the Free Officers for reform, since it weakened the traditional landed elite and helped the regime

district" in ruins, Gordon, Nasser's Blessed Movement, p. 27.

38 This means that, compared to other organizations, the Free Officers had no clear guidance for its platform. For detailed account, see Kirk J. Beattie, Egypt During the Nasser Years: Ideology, Politics, and Civil Society (Boulder: Westview Press, 1994), p. 54.

39 Ibid., p. 71.

40 Abd al-Azim Ramadan, al-Ikhwan al-Muslimun wa-l-Tanzim al-Sirri (Cairo: Maktab Madbuli, 1982), pp. 127-30.

41 Ibid., p. 84.

42 Beattie, Egypt During the Nasser Years, pp. 61-2. The Wafd also participated in the British-inspired war cabinet of 1942 that hurt the military, especially Nasser's generation. 
to reach out to the countryside.

Nasser then announced a three-year "transition period", during which the military would rule under martial law. The Free Officers went on to transform their organization into the Revolutionary Command Council (RCC), and formalized their own power with a temporary constitution in February of 1953. The regime briefly tolerated some opposition in early 1954, but they took final crackdown in April. This latter move stripped all opposition leaders, and led to the arrest of critical journalists, the dismissal of university professors who opposed to the regime, and the closing of university campuses. By August 1954, all key cabinet posts and control of the national state apparatus were assigned to the military. ${ }^{43}$

It is within this environment of a power transition that the Free Officers sought to resolve the issues surrounding the Islamic state advocated by the IM, and more importantly, the position of the IM vis-a-vis the regime. The IM leadership decided not to participate in the Liberation Rally. Instead, they maintained their focus on effecting Islamic constitutional transformation for Egypt. As Hudaybi stated in October 1953, "we (the IM) demand that the stipulation of the Qur'an in the Constitution be put into operation immediately. If the goals of our Revolution are for Islamic cause, the IM will support this revolution and becomes the backbone of the government". ${ }^{44}$ With the new regime consistently rejecting the call for an Islamic constitution, the IM began to demonstrate its power through street demonstrations in the late 1953. The Free Officers were deeply worried about the IM's consistent opposition. Meanwhile, the IM had also begun to realize that the regime had no intention of governing according to Islamic principles, and moreover seemed to be signaling that they would have only marginal power at best. Disillusion thus grew between the two groups. After a particularly unruly demonstration at Cairo University in January 1954, the Free Officers took the risky step of dissolving the IM. The regime justified this by arguing that their Supreme Guide Hudaybi had attempted to put the regime under his tutelage and spread anti-regime propaganda

\footnotetext{
43 Gordon, Nasser's Blessed Movement, pp. 134-6.

44 This statement appeared in the document, Free Officers, Revolutionary Command Council (1955), pp. 94-5.
} 
within the armed forces. ${ }^{45}$

The long struggle for constitutional reform also ended in late 1954, with both the former liberal constitution and an Islamic constitution being ruled out as organizing frameworks for the new Egyptian state. The decision to jettison the Islamic option was undoubtedly influenced by Nasser's realization that organizing the state according to Islamic principles would have dramatically strengthened the IM, at a time when it was a serious contender for power. The IM's unwavering struggle for an Islamic state organized according to shari'a law caused them to consistently reject compromise on this issue, for instance by acceding to some sort of power sharing arrangement.

\section{Transitions to Islamic Radical Politics}

In 1964, the stabilization of Nasser's political order was finally achieved through the promulgation of a new constitution. This was the successor to the June 23rd, 1956 constitution, which had guided Egyptians through the initial post-monarchy period. ${ }^{46}$ For the Free Officers, this 1964 Constitution outlined "the legitimating principles for the Revolution". ${ }^{47}$ And while its content was overly influenced by the interest of the Free Officers in securing power, it also represented a new formulation of the 1923 Constitution, one that provided for a greater concentration of power in the office of the president, and which as a result enabled Nasser to establish a highly centralized regime that controlled Egypt's politics and society. Throughout the 1960s, the core institutions of the new state remained the armed forces, the newly expanded mukhabarat (state security services), and a single organization, the Arab Socialist Union (ASU), through which all public participation

45 Mitchell, The Society of the Muslim Brothers, p. 281; Harris, Nationalism and Revolution in Egypt.

46 The 1964 Constitution marked the final outcome of the ideological battle that had raged since 1952. In 1956 Egypt held a referendum to approve the "temporary" national constitution, followed by the declaration of the National Charter in 1962 as the ideological basis for the Revolution. The 1964 Constitution can be regarded as the formalization of the Charter. On the development of Egypt's constitution, see also Rutherford, Egypt after Mubarak: Liberalism, Islam, and Democracy in the Arab World.

47 Ibid., p. 51. 
was channeled. ${ }^{48}$

The wave of persecution of the IM began in late 1954, following the assassination attempt on Nasser. Shortly after the incident, the IM was rounded up in what appeared to be a well-planned action. Thousands were sent to prison with or without trial, and a number of leading figures were sentenced to death by military tribunals, while many others managed to leave Egypt for Jordan, Syria, countries in the Gulf, and most notably, Saudi Arabia. ${ }^{49}$ For the IM members who remained in Egypt, the years between 1955 and 1962 were characterized by "internal struggles for organizational survival" 50 in the form of underground activism, partly because of the state's close surveillance of its activities and because of the execution or imprisonment of its leading figures.

This leadership gap in the IM was almost entirely the result of imprisonment, torture, and isolation carried out by Nasser's persecution of the group. It is not surprising that a clear ideology and set of guidelines for relations with the new state were not available. Beginning in 1958, there were efforts amongst the imprisoned members of the IM to address the leadership vacuum by making Sayyid Qutb a leading figure able to dispense spiritual advice. These efforts were relatively successful, and thus the early 1960s became a turning point within the IM's trajectory, in which signs of revival began to replace disillusionment. ${ }^{51}$ There are three major indicators of this change: first, during this period, prisoners started to exchange and discuss ideas, especially related to opposition strategies. Second, a communications network was built up, linking prisoners, and notably Qutb, to members and leaders on the outside. Third, Nasser relaxed his tight grip on the IM and released members with shorter prison sentences. ${ }^{52}$

Sayyid Qutb (1906-1966) is perhaps the most important theorist of

48 Between 1957 and 1960 the Free Officers began a gradual incorporation of its members, networks and clients to be transferred into the state. This network helped them to run the government. See, Gordon, Nasser's Blessed Movement, pp. 34-6.

49 Rais, "The Muslim Brotherhood in Egypt", pp. 181-3.

50 Barbara Zollner, "Prison Talk: The Muslim Brotherhood's Internal Struggle during Gamal Abdel Nasser's Persecution, 1954 to 1971", International Journal of Middle East Studies, vol. 39, no. 3 (2007), p. 412.

51 Ashour, "Lions Tamed?", p. 171.

52 Ibid., pp. 121-6. 
contemporary radical Muslim politics. But his relationship with the IM, was a complex one. Qutb was a moderately liberal-leaning intellectual during the 1940s. A literary critic by training, he returned to Egypt from a year-long stay in the United States as a committed Islamist activist. His interest in joining the IM grew in the early 1950s, when he regularly contributed to their publications, including al-Da'wah (The Call) and alMuslimun (the Muslims). In those publications, he harshly criticized the British occupation of Egypt, even calling for Muslims to form Kata'ib al-Fida' (Sacrifice Battalions) to fight against the British. Beginning in 1951, he was elected as the Head of the Information Department. By the time of the 1952 Coup, Qutb was a member of the Guidance Bureau. ${ }^{53}$

Qutb was among the IM leaders arrested in the first wave of persecution in 1954. He spent only eight months in prison until he was transferred to the Liman al-Turra prison hospital in 1956 due to ill health. It was in this prison hospital that Qutb was able to work on a number of projects. He continued his voluminous Qur'an commentary Fi Zilal al-Qur'an (Under the Shade of the Qur'an), revised his renowned book al-Adalat al-Ijtima'i fi al-Islam (Social Justice in Islam), and wrote short manuscripts. ${ }^{54}$ Qutb's most important work, Ma'alim fi al-Tariq (Milestones), although published after his release, was most probably written during these prison years. ${ }^{55}$ The prominence of Qutb's various works put him in a position of intellectual leadership within the organization, and made him central to Egypt's Islamic ideological changes in the crucial years of Nasser's persecutions.

This move toward Islamist ideological changes was facilitated by prisoner networks, which played a crucial role in elaborating and disseminating Qutb's ideas. Qutb was able to communicate and exchange thoughts with other prisoners during his hospitalization in the Liman

53 Ramadan, al-Ikhwān al-Muslimūn wa-l-Tanzim al-Sirri, p. 76. This brief biography was extracted from Adnan Musallam, From Secularism to Jibad: Sayyid Qutb and the Foundation of Radical Islamism (Westport: Praeger, 2005). See also, Haddad, "Sayyid Qutb", pp. 67-98; Muhammad Hafiz Diyab, Sayyid Qutb: Al-Khitab wa-l-Idiyulujiyya (Cairo: Dar al-Thaqafa al-Jadida, 1987), pp. 103-7.

54 William E. Shepard, "Islam as a 'system' in the later writings of Sayyid Qutb”, Middle Eastern Studies, vol. 25, no. 1 (1989), pp. 213-35.

55 Gilles Kepel, Muslim Extremism in Egypt: The Prophet and Pharaoh (Berkeley: University of California Press, 1989), p. 50. 
Tura prison. ${ }^{56}$ This enabled the prisoners to discuss and learn from Qutb's ideas, and upon their return to their various "home" prisons, they further engaged with the ideas. Hudaybi, who held the de jure leadership of the IM, definitely knew of these activities. ${ }^{57}$ It is quite clear that by 1958, Qutb's ideas had become the central discourse among the prisoners, which helped infuse a new spirit within the organization. Moreover, Qutb's ideas were also discussed outside the prison, through the members who regularly visited Qutb in prison and spread his ideas amongst those outside prison. ${ }^{58}$

This group, named in court as "Nizam 1965" (Organization 1965), was largely composed of former prisoners, some of whom had been incarcerated in the prison of Qanatir, as well as a large number of IM who had escaped the 1954 arrests. ${ }^{59}$ The new group was in close contact with Qutb, who acted as their spiritual guide. ${ }^{60}$ It soon became the most important forum for the new generation in the IM to disseminate and expand Qutb's ideas about the strategy for Islamist opposition. The Nizam 1965 also became the launch pad for forms of underground activities that echoed the purist organizational strategy introduced by Hasan al-Banna. ${ }^{61}$ Moreover, the group saw itself as the vanguard of Islamist activism called for by Qutb. As Haddad points out, "a member (of this group) needs to pass through several challenging stages of study, preaching, and persecution in order to reach their goal of establishing

56 Ibid., p. 28.

57 Between 1950 and 1960, the younger members at Qanatir prison were particularly inspired by Qutb's ideas. They began to preach the concept of takfir to other Muslims and government.

58 Zaynab Al-Ghazali, leader of al-Sayyidāt al-Muslimāt (the Muslim Sisterhood), provided a detailed account of the IM's efforts to circumvent the leadership gap that eventually led to the close association with Qutb's ideas. She mentioned that a number of the Brothers and Sisters visited Qutb and other prisoners and discussed many issues with them. Please see Zaynab Al-Ghazali, Ayyäm min Hayätī, (Cairo: al-Matba'a al-Adabiyya, 1987), pp. 57-60.

59 Ashour, "Lions Tamed?", p. 92.

60 Sayyid Quțb, Sayyid Qutb and Islamic Activism: A Translation and Critical Analysis of Social Justice in Islam, trans. by William E. Shepard (Leiden: E.J. Brill, 1996), p. 36.

61 R. Hrair Dekmejian, Islam in Revolution Fundamentalism in the Arab World, 2nd edition (Syracuse, N.Y.: Syracuse University Press, 1995). 
a just Islamic society". 62

Arguably, the organizational development of the IM and the role of Qutb in that development were not a secret to the official Supreme Guide, Hudaybi. ${ }^{63}$ Moreover, it seems that Hudaybi was aware of the ideological foundation of Nizam 1965, and made no effort to disband the group or to object to Qutb's theories. The underlying reason for Hudaybi's decision was likely related to the fact that while the IM experienced very tight political constraints under Nasser's regime, the activities of Nizam 1965 and the expansion of Qutb's ideas became viable means for preventing the IM from entering into a total decline. It is only in the late 1960s, when Nizam 1965 organized an armed insurrection against the regime, that Hudaybi began to take steps to denounce radical politics.

More accommodating principles regarding the Islamic state alternative were then adopted by Hudaybi's faction. ${ }^{64}$ One of the most important efforts in this de-radicalizing initiative was the publication of a book entitled Du'at la Qudhat (Preachers, Not Judges), which went on to underpin the IM's long-term moderation. This marked the historic rupture within Egyptian Islamism that led to the official leadership distancing itself from the radicals. The problem is that, Nasser's to the group of Nizam 1965 was swift and brutal. The group was brought to court, with members and collaborators accused of planning to overthrow the state system. At the same time, another massive purge of Islamist activists and the IM was launched. This wave of persecution resulted in the execution of six leaders of the IM, including Sayyid Qutb, in mid1966, as well as the imprisonment and torture of thousands of rank and file members. ${ }^{65}$

The fact that the group subscribed to an extreme ideology and had a militant method for an Islamic state was undeniable. For Nizam

62 Ashour, “Lions Tamed?”, p. 92.

63 Zollner, "Prison Talk", pp. 411-33.

64 Ibid.

65 Beattie, Egypt During the Nasser Years, p. 79. According to the IM's estimates, the number of people detained by Nasser in 1965 reached 20,000, of whom around 1,000 were brought before a military tribunal. It must be mentioned that it is unlikely that Nizam 1965 had concrete plans for terrorist activities. This issue is that, after Nasser's power consolidation in the 1960s, he still perceived IM as a threat to his power. See, Ashour, "Lions Tamed?", p. 183. 
1965, the absolute character of state power was the prime target of criticism, while the state system under Nasser represented the epitome of un-Islamic conduct. Thus although Qutb's theories did not explicitly mention about Nasser and his regime, he charged 'secular regime' with the ultimate crime of apostasy. Furthermore, Qutb's total rejection of the existing political system implied that the use of violence in order to bring about an Islamic revolution was legitimate. Qutb's Ma'alim fi al-Tariq contained an ideological commitment that said that "...violent struggle for an Islamic state is legitimate", ${ }^{66}$ and that the Nizam constitutes a model for Islamic radical politics in Egypt.

Qutb's ideas on society, politics and governance are firmly grounded in extreme interpretation of Islam, and that they are related to Hasan alBanna's own ideas. ${ }^{67}$ The two works that are primarily responsible for the perception of Qutb as a radical Islamist thinker are Under the Shade and Milestones, which represent a concrete elaboration of Hasan al-Banna's strategy and program for an Islamic state through the purification of society. But while Hasan al-Banna was the product of the 19th century "ancient regime" and the British colonial state, Qutb focused far more on Nasser's nationalist state. Qutb's understandings of community and agency were conditioned by the experience of witnessing a powerful, absolutist and secular state "... intrude into society as the colonial regime had never been capable of doing". Qutb evoked evil as an active and insidious force identified as taghut, by which he meant "deception that cannot endure the mere existence of truth ... for even if truth wished to live in isolation from deception - leaving victory to the decision of God - deception cannot accept this situation". ${ }^{68}$

Building upon these religious themes, Qutb sought to describe human political power by conflating the words: taghut and tughyan. Tughyan has to do with overstepping boundaries (including "going beyond disbelief"), whereas taghut is associated with "that which is worshipped

66 Ibid., p. 312.

${ }^{67}$ For a comparative analysis of Qutb's and al-Banna's thought, see Olivier Carre, "From Banna to Qutb and 'Qutbism': The Radicalization of Fundamentalist Thought under Three Regimes", in Egypt from Monarchy to Republic: A Reassessment of Revolution and Change, ed. by Shimon Shamir (Boulder: Westview Press, 1995), pp. 201-10.

68 Sayyid Qutb, al-`Adala al-Ijtima` iyya fi al-Islam (Beirut: Dār al-Shurūq, 1974). 
other than God". ${ }^{69}$ Here the notion of a modern Pharaoh that emerged during the Islam-liberal debate in the 1920s reappeared as a fundamental theme in Qutb's interpretation of the penetration of Nasser's regime into Egyptian society. Qutb argued that the arbitrary power of the state symbolized by Pharaoh could be conflated with Nasser's absolutist regime. Underlying Qutb's ideas was a conviction that the ordering of human affairs is the exclusive domain of God, and that "all other forms of human governance, as the source of authority and commands, are therefore equal to shirk (polytheism)" ${ }^{70}$

Effectively, Qutb drew upon Hasan al-Banna's ideas to envisage a far more intolerant, sophisticated and exclusive Islamic state. There are three main themes within Qutb's ideas that were influential in shaping the organizational imperatives of radical Islamist groups in the 1970s. The first is the concept of jabiliyya, which refers to the immoral, polytheist society of pre-Islamic Arabia, and which Qutb interpreted to also describe a state of being. According to Qutb, any individual, group or society that did not live according to Islam based on the shari'a was living in jähiliyya. This included those citizens of Muslim countries who were not living according to shari'a's tenets. Qutb argued that jähiliyya was "a destructive and corruptive force intent on eradicating the true Islamic path". ${ }^{71}$

Second, Qutb characterized the world as being polarized into dar al-harb (house of war), which was every part of the world that was non-Islamic, and dar al-Islam (house of Islam), which was the Islamic world. He argued that the dar al-harb was to be fought against and destroyed, and then replaced with a Muslim state based on the shari'a. In his notions of al-jäbiliyya and dar al-barb, Qutb was highlighting the universalism of Islam, which made it well-equipped to take over all other societies. Echoing Hasan al-Banna's vision, Qutb proclaimed Islam to be a complete system, and argued that the main purpose and message of the Qur'an was "political and social, not just spiritual". ${ }^{72}$ This political

${ }^{69}$ Ibid., p. 137.

${ }^{70}$ Kepel, Muslim Extremism in Egypt, p. 87.

71 Sayyid Qutb, Ma'alim fi al-Tariq (Beirut: Dār al-Shurūq, 1979), p. 23.

${ }^{72}$ Eric Davis, "Ideology, Social Class and Islamic Radicalism in Modern Egypt", in From Nationalism to Revolutionary Islam, ed. by Said Amir Arjomand (London: Palgrave Macmillan UK, 1984), p. 153. 
order would liberate humanity from the yoke of a secular system of state. $\mathrm{Kepel}^{73}$ noted, Qutb's polarization of the world into two systems made his "ideologies appealing, since they provided guidelines for analyzing the (Nasser's) declining regime."

The third main theme in Qutb's ideas was his interpretation of al-Banna's concept of jihäd to constitute a "revolt against (unbelieving) rulers". ${ }^{74}$ Making a point that still resonates today with the radical Islamists, Qutb stated in the mid-1960s:

“...we are the umma of Believers, living within a jähili society. Nothing relates us to state or to society and we owe no allegiance to either. As a community of believers we should see ourselves in a state of war with the state and society. The territory we dwell in is dar al-harb" ${ }^{35}$

Dissatisfied with the existing Islamist movement, Qutb asserted that social revolution "...provided the means to eradicate this state of jäbiliyya and to create the Islamic state mandated by the shari' $a$ ". Qutb conceptualized the need for revolution in terms of submission to the oneness of God (tawhid). He argued that Islam inherently requires the submission to this oneness, which in turn requires the "positive submission to God and negative revolt against submitting to other authority being they are concrete, metaphysical, or political".

Arguably, the seeds of revolution would only come about at a suitable juncture: "Qutb impressed upon them (Islamists seeking his approval for anti-state violence) the need for long-term educational endeavors to form cadres and militants while waiting for the opportune moment to strike". The importance of jibäd and the need to eradicate jäbiliyya societies brought Qutb to consider the necessity of creating "a distinct community of believers" that would take the lead in the destruction of the jäbiliyya. His worldview thus depicted the world as in a state of perennial conflict between those of the "party of God" and those of the jähiliyya societies.

These radical ideas, however, were not translated into organizational imperatives until the structural conditions necessary for their emergence appeared in the form of Nizam 1965. Nasser's death in 1971 and the

73 Kepel, Muslim Extremism in Egypt, p. 153.

74 Sayyid Qutb, Milestones (Indianapolis: American Trust, 1993), p. 91.

75 Qutb, Milestones, p. 98. 
subsequent political changes under his successor, Anwar Sadat, provided a new opportunity for the continued growth of these radical alternatives. In the 1970s, as Eric Davis ${ }^{76}$ remarked, "political activism of Islam became increasingly bifurcated and social and economic disorder pressures the activism into new forms of Islamist movements, which are thoroughly divorced (from the IM)". Egypt's defeat in the Arab-Israeli war in 1967 propelled new patterns of state-Islam relations in which Qutb's extreme and violence ideas found fertile ground for taking revolutionary solutions for an Islamic state.

\section{E. The Rise of Jamā'ah al-Islāmīyah and Tanzim al-Jihad}

As we have mentioned earlier, it is the role of institutions created by Nasser's regime that facilitated the changing character of mobilization for Islamic state, from a moderate to extreme interpretation of Islam. One may see that, after the Arab defeat in the 1967 war against Israel, one of the most crucial aspects of Egypt's Islamic turn was the effort to Islamize university students. This effort was aimed at fanning the increasing religious awareness among the youth. While in the early years of Sadat's presidency the Nasserist-leftist dominated the Egyptian student movements, in 1972 new "families" (usrab) and "associations" (jama'a) were beginning to surface for the first time. These groups had a religious character, and had their roots in "religious study clubs" on university campuses. ${ }^{77}$ They soon began to sponsor Islamic education programs, such as miscellaneous activities to producing publications, putting on summer camps, and organizing journeys to Mecca. ${ }^{78}$

Sadat's effort to mobilize Islam on university campuses was beginning to bear fruit by the time the 1973 war was launched. As Kepel ${ }^{79}$ has pointed out, "university life became more religious...largely with encouragement from the new (Sadat's) regime." As a result of the state's continuing support, Islamist groups varied and expanded the scope of

76 Davis, "Ideology, Social Class and Islamic Radicalism in Modern Egypt", p. 153.

77 Ashour, “Lions Tamed?”, p. 607.

78 Kepel notes that activities such as summer camps were generously sponsored and funded by the state. See, Kepel, Muslim Extremism in Egypt, pp. 191-2.

79 Ibid., p. 25. 
their activities to include more political ones. Again according to Kepel, ${ }^{80}$ these religious "families" in Egypt's universities were the sites where the young Islamist sympathizers and activists that later became the "Jamā'ah al-Islāmìyah" (Islamic Group, GI) first came together. They were the breeding ground for the cadres of the future Islamist groups.

In the mid-1970s, a more systematic and centralized strategy for encouraging Islamist student groups was initiated by their leaders, most notably 'Abd al-Mun'im, Abul Futuh, 'Issam al-Aryan, Abul 'ila al-Madi (Cairo, Alexandria and al-Minya), Nāgiḥ Ibrāhīm and Karam Zuhdi (Asyut University). ${ }^{81}$ This centralization was made possible by national student movements that came together around their shared support for the 1973 war. ${ }^{82}$ These groups of Islamist students were distinguished from the IM, and eventually formed a new organization that called itself "Jamā'ah alIslāmiyah". But at this time, each university group remained autonomous in terms of its activities, with no single ideology or clear platform being embraced by them all. What was obvious was their ultimate goal: al-da'wa (proselytizing) and al-'amr bil ma'ruf wal nahyi 'an al-munkar (ordering virtue and preventing vice). They were thus "the nearest approach to a youth movement with a religious character". ${ }^{83}$ Egypt's university campuses were gradually transformed during the 1970s by the increasing dominance of Islamist students, to the point that they came to be almost "governed" by young Muslim activists. These students worked to implement changes in the universities, in the curriculum taught, as well as by encouraging their fellow students to participate in Islamic activities, by halting lectures and classes during prayer times, by segregating the sexes in classrooms,

${ }^{80}$ Ibid., p. 137.

81 Ashour, "Lions Tamed?", p. 606.

82 Nāgih Ibrāhīm, Mìthāq al-'amal al-Islāmì (Egypt, 1984), p. 17.

83 Saad Eddin Ibrahim, "Anatomy of Egypt's Militant Islamic Groups: Methodological Note and Preliminary Findings", International Journal of Middle East Studies, vol. 12, no. 4 (1980), pp. 423-53; Ibrāhīm, Mìthāq al-'amal al-Islämì, p. 64. In the first national congress in 1974, the leading representatives from the universities agreed to form a defined structure for the Islamist student groups. Each university had a shura (consultative) council and an emir (leader). There was also a national emir al-umara'. Since the students were coming from a variety of political convictions and ideologies, each university leadership operated in an autonomous manner. Interview with Abu 'ila al-Madi, Cairo, December 10, 2015. 
and by prohibiting concerts, art performances and theatrical productions. Mohammad Haykal, described this 'sea change' in the environment at universities during the 1970s:

"Knowing they had the support of higher (governmental) authority, the Islamic students began to behave as if it was they who were running the universities. They decided what subjects were suitable to be taught, forcibly preventing, for instance, lectures to be given on Darwinism ... it was clear that the Islamist students were not simply tolerated by the authorities but actively encouraged by them." ${ }^{.4}$

By the late 1970s, such religious mobilization began to pay off: Egypt's students were markedly less interested in participating in the activities and demonstrations organized by the leftist student associations. An important phase for political Islam under Sadat was when Islamist groups began confronting leftist activists within the universities in the name of "protecting Islam". ${ }^{85}$ As the leftists withered and Sadat's support for Islamist students continued, the Jamā'ah al-Islāmìyah gained strong footholds in almost all of Egypt's universities.

Yet its rapid success and lack of a clearly formulated vision for society meant that while Jama'at was able to intensify its activism, it simultaneously became an ill-defined web of activists within a stretched organizational body that lacked clear direction for change. This was reflected after the mid-1970s, when the Jamā'ah al-Islāmìyah activities rapidly moved forward as regards promoting its political agenda outside university campuses. It began to mobilize its members, as well as the religiously inclined townspeople, against what it called "rampant evil behaviors". ${ }^{86}$ Sporadic violence began to occur on university campuses, as well as in the neighborhoods around them. Between 1977 and 1979, after its leaders' success in winning seats on the Executive Council of the National Students Union, ${ }^{87}$ the Jamā'ah al-Islāmīyah began a campaign

84 Muhammad Hasanayn Haykal, Autumn of Fury: The Assassination of Sadat (New York: Random House, 1983), p. 133.

85 Ibid., p. 138; Ashour, "Lions Tamed?", pp. 607-8.

${ }^{86}$ Hamied N. Ansari, “The Islamic Militants in Egyptian Politics”, International Journal of Middle East Studies, vol. 16, no. 1 (1984), pp. 123-44.

87 Three leaders of the Jama'at who won seats in the National Student Union were Tal'at Qasim, Abu 'ila al-Madhi, and Abdulghani Taha. Interview with al-Madhi, 
in Cairo University that saw them asserting “...we knew that religion is not only to conduct da'wa, but is also the establishment of the Islamic state...to achieve (such a goal), it is an essential precondition that we work to eradicate those practices of jähiliyy a" ${ }^{88}$ Simultaneously, similar activities were undertaken on other university campuses, including Asyut University. ${ }^{89}$

The relative ease with which the Jama'at activists tapped the use of violence in confronting the leftist organizations and in spreading their religious activism underlined the strong support that they were receiving from the regime. At the same time, the nature and extent of their activities ultimately helped them to guarantee themselves a greater chance of expanding their influence and growth. For instance, in Asyut, one of the organization's strongholds in Egypt's southern province, the Jama'at leaders found themselves with sufficient popular legitimacy to carry out the da'wa and to enforce certain Islamic behaviors. Yet it bears noting that their desire to do so was also a strong indication that they had begun to adopt a more confrontational and militant strategy. That strategy later turned out to be directed not only against leftists and Nasserists, as well as against Christian Copts, but also against the state authority itself.

As the uncontrolled religious activism pursued by the Jama'at intensified, it became apparent that clear intellectual guidance was required so as to transform their strength into concrete political achievements. In 1977, a number of the Jama'at leaders, particularly from Cairo, Alexandria and the Nile Delta, joined the IM, thereby strengthening the politically moderate wing of Egyptian Islamists. Some other leaders, who were mainly from Asyut, were more inclined to join the jihadist groups that had begun to emerge in 1974. These groups were imprisoned-members of Nizam 1965. Then in 1979, a Cairo-Jamā'ah leader, Karam Zuhdi, as well as various Asyut-leaders, met Muhammad 'Abd al-Salam Farag, a jihadist leader released from prison in 1978. The meeting resulted in an agreement to unite and to coordinate their efforts to form a united jihadist organization, the Jama'at Islamiya (JI). ${ }^{90}$ The alliance between

Cairo, 10 December, 2007.

88 Ansari, “The Islamic Militants in Egyptian Politics”, p. 131.

89 Ibid., p. 137.

90 Ashour, "Lions Tamed?", p. 608. 
the Islamist-students and a prominent leader of the Nizam 1965 spurred further radicalization of Islam in which revolutionary jihad came to increasingly define the contours of the mobilization for an Islamic state.

Jihadist leaders had begun to operate and recruit their cadres soon after their release. Between 1972 and 1974, approximately 20 small factions of jihadist groups operated in Cairo and Asyut, but only three of these later became major organizations. ${ }^{91}$ The first of these is the Technical Military Academy Group (al-Fanniya al-Askariya). ${ }^{92}$ This group attempted to seize the Military Academy in Asyut in 1974, in order to launch a coup during Sadat's speech in the Academy. Their goal was to seize weapons and then assassinate the President. Although their attempt failed, ${ }^{93}$ it was the first jihadist group that publicly declared Egypt's need for an Islamic revolutionary transformation. This group was led by Salih Sirriya, a member of Nizam 1965 who believed that jihad was a tool capable of changing a political system that was deemed jäbiliyya and 'infidel'.

In a document entitled Epistle of Faith (Risalat al-Iman), Salih Sirriya asserted that "all of the current Islamic regimes are infidel and jäbiliyya regimes". ${ }^{44}$ Sirriya regarded the use of violence as a legitimate way to change "the dominant rule", since doing so was justified in Islamic jurisprudence, in order to anesthetize and excommunicate regimes. The document also stated that, "the House of Islam (dar al-Islam) is the one in which the word of God is the uppermost... and rule (government) is conducted according to the Quran...the House of Kuffar (non-believers) is one in which the word of non-belief is the highest and is not ruled by the Quran." Consequently, the only way to change from "infidel" rule is through "jihād". What this group meant by jihad is "...a way to change

91 Dekmejian, Islam in Revolution Fundamentalism in the Arab World; Ashour, “Lions Tamed?", p. 608.

92 This organization was known by several names. Sometimes, they referred to themselves as the Islamic Liberation Organization (since its foundation was closely related to Jordan's Hizb al-Tahrir). Some others called them Muhammad's Youth (Shabab Muhammad). See Saad Eddin Ibrahim, "Egypt's Islamic Militants”, MERIP Reports, no. 103 (1982), pp. 5-15.

93 The leader of the group, Salih Siriyya, was executed after the failed coup, and the other members of the group were imprisoned.

94 Ansari, "The Islamic Militants in Egyptian Politics", p. 191. 
governments and to establish the Islamic state, which is a compulsory duty of every Muslim."

The second group is The Society of Repudiation and Emigration (Jama'at al-Takfir wa al-Hijra). This group's name points toward its radical message of "repudiating those institutions and persons deemed unbelievers", and the need for "withdrawal from jäbiliyya society". ${ }^{95}$ The ideology of this organization built upon the model of the Prophet Muhammad's Hijra from Mecca to Medina to establish a true Islamic order. The group was established by Shukri Mustafa, shortly after his release from prison in 1970, though the initial members consisted of people he had approached and recruited during his six years in prison. The group's ideology did not differentiate between the state and society, since as Mustafa wrote in his memoir, both society and the state are jäbiliy institutions that must be "purified". ${ }^{96}$

It is because of this lack of differentiation that the members of Takfir wa la-Hijra believed that they must maintain their distance from state and society, and indeed should adopt a negative and violent attitude toward them. Mustafa, for instance, adopted Hijra (immigration) and isolation as disciplinary techniques and a necessary strategic step towards the ultimate goal, i.e., the Islamic state. Consequently, the group required its members to isolate (u₹la) themselves from government institutions and to completely ostracize society and its members. They also rejected compulsory military service and employment in government departments and institutions. ${ }^{97}$

As part of a disciplinary method for the organization, Mustafa forbade his members from praying in mosques constructed and sponsored by the state. This was because according to Takfir wa al-Hijra, the basic character of the state's reality was jähiliyya, and this character would infect all of its activities. As such, the only way to escape such an infidel situation was to join the Jama'at. Between his release in 1971 and his execution in 1977, Mustafa succeeded in recruiting approximately 2,000 members to Jama'at al-Takfir in Asyut

The third jihadist group that came out of prison is Jihad

95 Ibrahim, "Anatomy of Egypt's Militant Islamic Groups", p. 96.

96 Kepel, Muslim Extremism in Egypt.

97 Ansari, "The Islamic Militants in Egyptian Politics", pp. 123-44. 
Organization of Egypt (Tanzim al-Jihad al-Misr). Muhammad 'Abdul Salam Farag established this group in Cairo in 1979. Farag's group began to form after Nasser's wave of imprisonment, and expanded in the mid-1970s through the efforts of masterful recruiters such as Ayman al-Zawahiri, Hani al-Siba'i, Anwar Ukasha, and Muhammad Qutb. ${ }^{98}$ Farag was the author of al-Fariyda al-Ghäiba (the Neglected Duty), an elaborate book on the strategy of Sayyid Qutb that espoused jihad and violence as legitimate paths toward an Islamic state. This book became the members' intellectual and ideological frame of reference for executing the group's military and political operations. Farag argued that the duty of jihäd - understood purely as armed struggle — was a duty that had been neglected by the Muslim faithful. He argued that:

"Despite its crucial importance for the future of our Faith, the jihad has been neglected, maybe even ignored, by men of religion of our age. They know however, that jihad is the only way to reestablish and re-enhance the power and glory of Islam, which every true believer desires wholeheartedly. There is no doubt the idols upon earth will not be destroyed but by the sword - and thus establish the Islamic state and restore the caliphate. This is the command of God and each and every Muslim should, hence, do his utmost to accomplish this precept, having recourse to force if necessary." ${ }^{99}$

Like Qutb, Farag advocated the replacement of the Egyptian regime with a caliphate, that is, a community of believers governed by the precepts of Islam and led by a religious leader (Caliph). To Farag, jihad represented a moral and religious imperative incumbent upon every Muslim. He thus specifically called for violence within the context of revolution, arguing that only by armed struggle could an Islamic state ever be realized.

\section{F. The Abortive Jihadist-Revolution in 1981}

Members of Nizam 1965 were serious students of Sayyid Qutb. For instance, Farag based his theory of jihadist revolution on Qutb's view that

98 Ashour, "Lions Tamed?", p. 111.

99 See, Muhammad 'Abdul Salam Farag, "The Neglected Duty", in The Neglected Duty: The Creed of Sadat's Assassins and Islamic Resurgence in the Middle East, ed. by Johannes J.G. Jansen (New York: Macmillan, 1986), p. 172. 
there is a "need to build a small, militant number of believers that link (them) with broader Muslim society and mobilize the society's support for (an) Islamic state (dar al-Islam)". ${ }^{100}$ But in al-Fariyda al-Ghäïba, Farag elaborated Qutb's theory, saying that jihad should begin with a careful social, political, and economic analysis of society. He argued that such an analysis is necessary for Islamists to "... decide upon and select the most appropriate and most effective method for change", ${ }^{101}$ such as the shape and scale of the Islamic revolution, the forms of violence and the tactics to be used, and the level of mobilization. Farag further underlined the "imperativeness of establishing a secret (purified) society (jama'at)" responsible for penetrating the security forces, the army, collecting intelligence information, and recruiting sympathetic military personnel and officers into the organization, thus facilitating the achievement of a total Islamic revolution. ${ }^{102}$

In the late 1970s, inspired by Farag's vision and emboldened by the increasing number of jihadists, leaders of al-Jihad shifted their focus to the practical and organizational aspects of their plan to seize control of the jabily state and to establish an Islamic one. Consequently, a middle ranking military officer who had served in the State Security Intelligence (SSI), Abbud al-Zumar, was joined al-Jihad in 1978. ${ }^{103}$ Al-Zumar quickly took on a major role in planning and strategy, while the military leaders of al-Jihad, Esam al-Qamari, concentrated on the military training.

The plans were outlined in a document entitled Pillars of Continuity, which details major strategies that the Islamists deemed essential for achieving the Islamic Revolution. ${ }^{104}$ An in depth description of these strategies was provided in a document entitled The Stages of Islamic Movement Development. The document states that "the plan depended on constructing an organizational structure that is capable, by providing

100 Qutb, Ma'alim fi al-Tariq, p. 79.

101 Farag, "The Neglected Duty", p. 234.

102 Ibid., p. 236.

103 Abbud al-Zumar was a highly ranked officer in the Egyptian Army. He had a long career, military training, and extensive experience in the Army Intelligence since the October War of 1973. This background contributed to the development of al-Jihad organization and its military strategy.

104 Abbud al-Zumar, The Method of the Islamic Jihad Group (unpublished, 1986), pp. 5-17. 
man-power and supplies, of seizing power and completely controlling the vital state institutions and command centers on which the regime relies to rule the country, thereby paralyzing its ability to counter the Islamic move". ${ }^{105}$ To protect their leaders, the plan aimed at "preventing the regime from taking certain measures or actions to confront Islamists, such as ambushing, assassinating, and arresting their influential officials and figures." Furthermore, according to the plan, the organization should "disable the communications and transportation lines and deter the enemy reserve forces from participating in the battle."

The document also emphasized the urgent task of "preparing Islamist actors to be capable of mobilizing the masses and inciting and goading them into participating in the revolution to demonstrate public support and hence deter foreign intervention... with the necessity of restraining all foreign agents working in the country". ${ }^{106}$ Although the role of the masses was not made completely clear in the plan, it is obvious that the strategy depended heavily on the tactics and choices of the organization's military leaders, who were at that time enlisted in the army.

The original plan for revolution, as designed by Abbud al-Zumar, required a three-year period of preparation before undertaking any action. But a series of unexpected events prompted a strategic change in the jihadists' plan. The first of these took place a few months after the plan had gained an approving fatwa from Sheikh Mohammad Omar Abdulrahman, when the authorities detected whispers about the planned operation. Sadat's response was to arrest thousands of members of the political opposition in September 1981, especially the IM and leaders of the Jamā'ah al-Islāmīyah. The latter group included nine leaders of jihadist organizations and members of its Shura Council. ${ }^{107}$

Another significant event that affected the plotters was the arrest of group member Nabeel al-Maghribi while attempting to buy weapons from a local arms dealer in Asyut. ${ }^{108}$ Even more dangerous was that the intelligence and security forces were becoming more aware of alZummar's role in al-Jihad. With the group increasingly exposed and thus

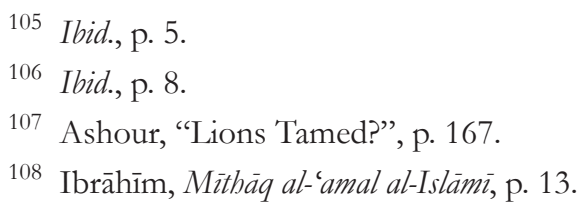


endangered, they decided to move more quickly than had been called for by their original, three-year plan. As a result, Farag, after meeting with his fellow jihadist leaders in late September 1981, decided that their first move must be to assassinate President Sadat. After the approval of the assassination plan, Khalid al-Islambuli was able to help three members of the jihadist movement to infiltrate his army unit. The assassination was carried out on October 6, 1981.

According to the plan, immediately after assassinating Sadat, the organization was supposed to move strategically on two fronts simultaneously, the first in the south and the second in Cairo. The Cairo portion of the plan called for armed units from the organization to seize and hold the television and radio stations, and to broadcast a statement about the "victory of Islamic revolution". ${ }^{109}$ The move was supposed to be concurrent with another unit's move to prevent or at least deter the police and state security forces from intervening and thus hindering the plan by attacking them in their barracks and at other locations in Cairo and Giza. In the south, the plan was to seize all of the state security buildings and compounds in Asyut and thus to dominate the south entirely, before moving north to Cairo to reinforce their co-revolutionaries. ${ }^{110}$

But aside from successfully assassinating Sadat, the group failed to fully execute any of these moves or to achieve any of these goals. In Asyut, the security forces were able to put down the insurgency within two days, regaining control of the region and arresting many of the Islamist leaders. This included the arrest of Khalid al-Islambuli and two other participants in the assassination. The government immediately formed different security committees consisting of members from several security forces and institutions. ${ }^{11}$

While the jihadists were unsuccessful at carrying out their plan, according to the Minister of the Interior Abu Basha in the 1980s, their readiness for action did take the government by surprise. Basha also noted that the government was taken aback by "the size and sophistication of these militant Islamist groups". ${ }^{112} \mathrm{He}$ asserted that the security forces

\footnotetext{
109 Zumur, The Method of the Islamic Jihad Group, p. 12.

110 Ibrāhīm, Mìthāq al-'amal al-Islāmì.

111 Kepel, Muslim Extremism in Egypt, p. 211.

112 Ibid., p. 222.
} 
realized for the first time that they were facing:

"A pyramid-like organization with several bases and leadership levels that has tremendous resources and capabilities as to members, armaments, and training that exceeded all of the state's preliminary estimates. Therefore, a race with time became a vital variable to prevent any additional exacerbation, especially after finding new and dangerous evidence about the movement size and capabilities. The evidence included discovering large stocks of weapons of all types...hundreds of machine guns, rifles, handguns, RGB guns, hand grenades...large quantities of ammunition and explosives". ${ }^{113}$

It seems clear that the jihadists were pushed into abortive action due to external factors. Of these, two were particularly important: First, there was the unexpected selection of Khalid al-Islambuli to participate in October's military parade. Secondly, Sadat's massive arrest campaign in September 1981 made the group's leaders increasingly worried that the security forces would discover their plans. They thus reasoned that since the state's attack on them was inevitable, it would be wiser if they moved first.

\section{G. Concluding Remarks}

As the purpose of this article is to explain the lineages of changes in behavior of Ikhwan al-Muslimun, the two episodes of organizational development in the IM has offered several answers that illustrate when and how moderate and modest Islamic movement has transformed into radical and violent Islamic groups. It is the interaction between institutional changes and opportunities that explain why a radical ideology arose, and how extreme and violence interpretation of Islam were politicized during the stabilization of political order in Egypt. Ideological approaches to the phenomenon, as most of cultural studies have suggested, tend to interpret the emergence of Islamic ideology by focusing on their cultural dimension. As a result, there are no significant differences between the historical, political, and social profiles among the Islamic movements that developed between before and after Egypt's revolution.

A closer look at the forms of mobilization for the struggle for

113 Ibid., p. 220. 
Islamic state in post-Nasser's revolution provides a more persuasive argument in regards to the contrast between two different periods of IM's organizational development. Two aspects of Egypt's institutional history explain the variations between the IM under Hasan al-Banna in the 1930s and the radical and violence appeals following Qutb's construction of Islamic state ideas in the 1960s. The first involves attempts at the collapsing monarchy, especially in the post-independence Egypt, that triggered the Muslim thinkers such as Hasan al-Banna to form an organization in the struggle for Islamic state. The IM leadership constructed a new forms of strategy for Islamic state mobilization at a point when they had experienced a unique sense of community based on their past glory as a political power, their resistance to the secular state, and their strong ties with the new emerging ideologues. The conflict between the IM and Nasser's regime has meant to discard the secularsocialist option for statehood in favour of a radical, extreme vision in the struggle for Islamic state.

However, the relations between the IM and the state experienced an unintended transformation accompanied by the emergence of a number of groups that favored a revolutionary path: Jamā'ah al-Islāmìyah and Tanzim al-Jihad. Nasser's repression of the IM, especially severe and brutal suppression of any aspirations during the 1950's and 1960's, and the subsequent political imprisonment for the newly emerging leadership, led the IM to conflate the ideas of a rebellion against Sadat. Consequently, the use of force during Nasser's revolution unintentionally narrowed the ability to convince the Islamic activists of the benefits of Sadat's institutional building. Nasser's violence created opportunities for the marginalized IM leaders such as Qutb to develop extreme ideas drawing secular state as taghut and a threat for Islam. These circumstances were largely responsible for deepening radical and violence extremism in Egypt's Islamic groups, especially during the 1970s. 


\section{Bibliography}

Al-Banna, Hasan, "Naẓrāt fỉ iṣlāḥ al-Nafs", in Tą̣kirat al Hasan Al-Banna, Cairo, 1956.

----, Five Tracts of Hasan Al-Banna (1906-1949), trans. by Charles Wendell, Berkeley: University of California Press, 1978.

----, Majmu at rasa'il al-Imam al-shabid Hasan Al-Banna, Beirut: Dar alDa'wa, 1990.

Al-Ghazali, Zaynab, Ayyàm min Hayātì, Cairo: al-Matba'a al-Adabiyya, 1987.

Al-Zumar, Abbud, The Method of the Islamic Jihad Group, unpublished, 1986.

Ansari, Hamied N., "The Islamic Militants in Egyptian Politics", International Journal of Middle East Studies, vol. 16, no. 1, 1984, pp. 123-44.

Ashour, Omar, "Lions Tamed? An Inquiry into the Causes of DeRadicalization of Armed Islamist Movements: The Case of the Egyptian Islamic Group", Middle East Journal, vol. 61, no. 4, 2007, pp. 596-625.

Beattie, Kirk J., Egypt During the Nasser Years: Ideology, Politics, and Civil Society, Boulder: Westview Press, 1994.

Carre, Olivier, “From Banna to Qutb and 'Qutbism': The Radicalization of Fundamentalist Thought under Three Regimes", in Egypt from Monarchy to Republic: A Reassessment of Revolution and Change, ed. by Shimon Shamir, Boulder: Westview Press, 1995.

Cleveland, William L., A History of the Modern Middle East, Boulder, Colo: Westview Press, 1994.

Crecelius, Daniel Neil, "The Ulama and the State in Modern Egypt", Ph.D Dissertation, Princeton: Princeton University, 1967.

Davis, Eric, "Ideology, Social Class and Islamic Radicalism in Modern Egypt", in From Nationalism to Revolutionary Islam, ed. by Said Amir Arjomand, London: Palgrave Macmillan UK, 1984.

Dekmejian, R. Hrair, Islam in Revolution Fundamentalism in the Arab World, 2nd edition, Syracuse, N.Y.: Syracuse University Press, 1995.

Diyab, Muhammad Hafiz, Sayyid Qutb: Al-Khitab wa-l-Idiyulujiyya, Cairo: 
Dar al-Thaqafa al-Jadida, 1987.

Esposito, John L., Islam and Politics, Syracuse: Syracuse University Press, 1984.

Farag, Muhammad 'Abd al-Salam, "The Neglected Duty", in The Neglected Duty: The Creed of Sadat's Assassins and Islamic Resurgence in the Middle East, ed. by Johannes J.G. Jansen, New York: Macmillan, 1986.

Free Officers, Revolutionary Command Council, 1955.

Gordon, Joel, Nasser's Blessed Movement: Egypt's Free Officers and the July Revolution, New York: Oxford University Press, 1992.

Haddad, Y., "Sayyid Qutb: Ideologue of Islamic Revival", in Voices of Resurgent Islam, ed. by John L. Esposito, Oxford: Oxford University Press, 1983, pp. 67-98.

Hafez, Mohammed M., Why Muslims Rebel: Repression and Resistance in the Islamic World, Boulder: Lynne Rienner Pub, 2003.

Hall, Peter A. and Rosemary C.R. Taylor, "Political Science and the Three New Institutionalisms", Political Studies, vol. 44, no. 5, 1996, pp. 936-957 [http://dx.doi.org/10.1111/j.1467-9248.1996.tb00343.x].

Harris, Christina Phelps, Nationalism and Revolution in Egypt: The Role of the Muslim Brotherhood, Berkeley: Stanford University Press, 1964.

Haykal, Muhammad Hasanayn, Autumn of Fury: The Assassination of Sadat, New York: Random House, 1983.

Heyworth-Dunne, J., Religious and Political Trends in Modern Egypt, Washington: Publ. by the author, 1950.

Hourani, Albert, Arabic Thought in the Liberal Age, 1798-1939, Cambridge: Cambridge University Press, 1983.

Husayni, Ishaq Musa, The Moslem Brethren: the Greatest of Modern Islamic Movements, Westport: Hyperion Press, 1956.

Ibrāhīm, Nāgih, Mìshāq al-'amal al-Islāmì, Egypt, 1984.

Ibrahim, Saad Eddin, "Anatomy of Egypt's Militant Islamic Groups: Methodological Note and Preliminary Findings", International Journal of Middle East Studies, vol. 12, no. 4, 1980, pp. 423-53.

----, “Egypt's Islamic Militants", MERIP Reports, no. 103, 1982, pp. 5-14 [http://dx.doi.org/10.2307/3011365]. 
Kepel, Gilles, Muslim Extremism in Egypt: The Prophet and Pharaoh, Berkeley: University of California Press, 1989.

Lombardi, Clark Benner, "State Law as Islamic Law in Modern Egypt: The Amendment of Egyptian Constitution and the Article 2 of Jurisprudence of the Supreme Constitutional Court of Egypt", Ph.D Dissertation, Columbia: Columbia University, 2001.

Mitchell, Richard P., The Society of the Muslim Brothers, New York: Oxford University Press, 1993.

Musallam, Adnan A., From Secularism to Jihad: Sayyid Qutb and the Foundations of Radical Islamism, Westport: Praeger, 2005.

Qutb, Sayyid, al-'Adala al-Ijtima` iyya fi al-Islam, Beirut: Dār al-Shurūq, 1974.

----, Ma'alim fi al-Tariq, Beirut: Dār al-Shurūq, 1979.

----, Milestones, Indianapolis: American Trust, 1993.

----, Sayyid Qutb and Islamic Activism: A Translation and Critical Analysis of Social Justice in Islam, trans. by William E. Shepard, Leiden: E.J. Brill, 1996.

Rais, Mohammad Amien, "The Muslim Brotherhood in Egypt: Its Rise, Demise, and Resurgence", Ph.D Dissertation, Chicago: The University of Chicago, 1981.

Ramadan, Abd al-Azim, al-Ikhwān al-Muslimün wa-l-Tanzim al-Sirri, Cairo: Maktab Madbuli, 1982.

Rutherford, Bruce K., Egypt after Mubarak: Liberalism, Islam, and Democracy in the Arab World, Princeton: Princeton University Pres, 2008.

Shepard, William E., "Islam as a 'system' in the later writings of Sayyid Qutb”, Middle Eastern Studies, vol. 25, no. 1, 1989, pp. 31-50 [http:/ / dx.doi.org/10.1080/00263208908700766].

Thelen, Kathleen and Sven Steinmo, "Historical Institutionalism in Comparative Politics", in Structuring Politics: Historical Institutionalism in Comparative Analysis, ed. by Sven Steinmo, Kathleen Thelen, and Frank Longstreth, Cambridge: Cambridge University Press, 1992.

Wickham, Carrie Rosefsky, Mobilizing Islam: Religion, Activism and Political Change in Egypt, New York: Columbia University Press, 2002. 
Zollner, Barbara, "Prison Talk: The Muslim Brotherhood's Internal Struggle during Gamal Abdel Nasser's Persecution, 1954 to 1971”, International Journal of Middle East Studies, vol. 39, no. 3, 2007, pp. 411-433.

Zubaida, Sami, "The Quest for the Islamic State", in Islam, the People and the State: Political Ideas and Movements in the Middle, New York: Routledge, 1989. 
Ali Munhanif \& M. Dahlan 